\title{
PENERAPAN HIGIENE SANITASI JASA BOGA PADA KATERING GOLONGAN A2 DAN GOLONGAN A3 DI KOTA PALANGKA RAYA PROVINSI KALIMANTAN TENGAH
}

\author{
Karina Septea Asie Sawong1, Dini Ririn Andrias², Lailatul Muniroh² \\ ${ }^{1}$ Program Studi Ilmu Gizi Fakultas Kesehatan Masyarakat Universitas Airlangga, Surabaya \\ ${ }^{2}$ Departemen Gizi Kesehatan, Fakultas Kesehatan Masyarakat, Universitas Airlangga, Surabaya \\ Email: karinasawong@yahoo.co.id
}

\begin{abstract}
ABSTRAK
Perkembangan katering baru yang pesat tanpa diimbangi pengawasan dari pihak berwenang dalam bidang keamanan pangan dapat menimbulkan kasus keamanan pangan. Penelitian ini bertujuan untuk menganalisis penerapan higiene sanitasi jasa boga pada katering golongan A2 dan golongan A3 di Kota Palangka Raya. Penelitian ini dilaksanakan dengan rancangan observasional bersifat deskriptif non hipotesis. Data primer didapatkan melalui wawancara tentang karakteristik katering pada 10 pemilik katering (golongan A2 sebanyak 3 katering dan golongan A3 sebanyak 7 katering) dan observasi tentang bangunan, peralatan, ketenagaan, fasilitas sanitasi, makanan serta prinsip higiene sanitasi katering sampel. Sampel dipilih berdasarkan teknik purposive. Data dianalisis secara deskriptif. Hasil penelitian menunjukkan seluruh katering masih belum memenuhi kelaikan fisik dalam penerapan higiene sanitasi jasa boga (katering golongan A2 nilai 70-74; golongan A3 nilai 74-83). Penerapan higiene sanitasi jasa boga dalam prinsip tiap variabel pada beberapa katering sudah memenuhi persyaratan. Penilaian kualitas mikrobiologi terhadap menu sayuran masak pada 3 (tiga) katering menunjukkan angka kuman E.coli 0/g. Kesimpulan penelitian secara umum dalam prinsip penerapan higiene sanitasi serta kualitas mikrobiologi sudah dipenuhi oleh katering golongan A2 dan golongan A3 di Kota Palangka Raya. Namun, secara kelaikan fisik, masih harus diperbaiki. Penerapan higiene sanitasi jasa boga pada katering ini diharapkan menjadi acuan memperoleh sertifikat laik higiene serta informasi bagi Dinas Kesehatan untuk verifikasi penerapan higiene sanitasi jasa boga di Palangka Raya.
\end{abstract}

Kata kunci: E.coli, higiene sanitasi, katering

\begin{abstract}
The rapid development of new caterings without followed by supervision from the authorities in term of food safety could lead to food safety cases. This study aimed to analyze the application of hygiene sanitation in catering class A2 and A3 in Palangka Raya. This research was conducted with descriptive observational design non-hypothesis. The primary data obtained through interview about characteristics of catering at 10 selected caterings ( 3 caterings class A2 and 7 caterings class A3) and observation of building, sanitary facilities, equipments, food handlers, foods, principles of hygiene and sanitation, and quality of food microbiology. Sample was selected based on purposive technique. Data were analyzed descriptively. The result showed entire catering still does not meet physical requirements in the application of hygiene sanitation catering (catering group A2 grades 70-74; class A3 grades 74-83). The application of principles hygiene and sanitation each variable in several caterings was met requirements. Assessment of the microbiological quality of vegetables menu in 3 caterings shows number of bacteria E.coli were $0 / g$. The conclusion of research in general is that principle the application of hygiene sanitation principle and microbiological quality are met by the catering class A2 and A3 in Palangka Raya. However, the physical feasibility still needs to be improved. Application of hygiene and sanitation in caterings are expected to be a reference to obtain hygiene certificate acceptance as well as information to Health Department for verify the application of hygiene and sanitation catering in Palangka Raya.
\end{abstract}

Keywords: E.coli, hygiene and sanitation, catering

\section{PENDAHULUAN}

Higiene sanitasi merupakan upaya untuk mengendalikan faktor risiko terjadinya kontaminasi terhadap makanan, baik yang berasal dari bahan makanan, orang, tempat dan peralatan agar aman dikonsumsi. Menurut Astawan yang dikutip oleh Sari (2012), makanan yang aman adalah yang tidak tercemar, tidak mengandung mikroorganisme dan 
bahan kimia berbahaya, telah diolah dengan tata cara yang benar sehingga sifat dan zat gizinya tidak rusak serta tidak bertentangan dengan kesehatan manusia.

Semakin maju teknologi dan bertambahnya aktivitas pada masa sekarang membuat masyarakat lebih memilih cara praktis dalam penyelenggaraan makanan bagi individu, keluarga maupun pada acara atau kegiatan. Hal ini yang mendorong pertumbuhan jasa boga seperti rumah makan, katering, bahkan pedagang makanan kaki lima. Jasa boga adalah usaha pengelolaan makanan yang disajikan di luar tempat usaha atas dasar pesanan yang dilakukan oleh perseorangan atau badan usaha (Permenkes RI, 2011).

Jasa boga yang adalah katering terdiri atas golongan $\mathrm{A} 1$, golongan $\mathrm{A} 2$, golongan $\mathrm{A} 3$, golongan $\mathrm{B}$, dan golongan $\mathrm{C}$. Katering golongan A2 dan golongan A3 dibedakan dari adanya dapur khusus yang digunakan untuk memproduksi makanan. Katering golongan A2 merupakan katering yang melaksanakan proses produksi makanan yang sudah memiliki karyawan namun masih menggunakan dapur rumah tangga untuk melaksanakan produksi, sedangkan katering golongan A3 merupakan katering yang sudah memiliki seluruh kriteria katering golongan A2 namun dalam proses produksi makanan sudah menggunakan dapur khusus.

Masalah keamanan pangan masih merupakan masalah penting dalam bidang pangan di Indonesia serta perlu mendapat perhatian khusus dalam program pengawasan pangan. Kejadian keracunan makanan yang terjadi di Kalimantan Tengah berdasarkan data dari Badan POM tahun 2013 tercatat 48 orang korban pada KLB keracunan makanan dari katering hajatan nikah di Kabupaten Kapuas Kalimantan Tengah. Katering yang melayani merupakan katering keluarga dan termasuk dalam katering golongan A2.

Penelitian ini bertujuan untuk menganalisis kelaikan fisik dan prinsip higiene sanitasi pada seluruh proses produksi makanan katering golongan A2 dan golongan A3. Katering golongan A2 dan golongan A3 dipilih berdasarkan keadaan katering yang ada di Kota Palangka Raya masih terdiri dari katering golongan A1, golongan A2, dan golongan A3 saja. Untuk katering golongan
B dan golongan $\mathrm{C}$ hingga saat ini belum tersedia. Katering yang ada di Kota Palangka Raya tidak seluruhnya terdaftar di dinas terkait. Jumlah katering yang terdaftar yaitu 8 katering pada Dinas Kesehatan, 4 katering pada Dinas Perindustrian dan Perdagangan, dan 5 katering pada Dinas Pariwisata.

Penilaian kelaikan fisik dan prinsip higiene sanitasi jasa boga merupakan salah satu upaya untuk mengendalikan keamanan pangan saat proses produksi makanan. Dengan adanya pengendalian proses produksi, dapat meminimalkan risiko terjadinya kontaminasi terhadap makanan, baik yang berasal dari bahan makanan, penjamah makanan, tempat dan peralatan agar aman dikonsumsi.

\section{METODE}

Rancangan penelitian yang digunakan merupakan rancangan penelitian observasional bersifat deskriptif non-hipotesis berdasarkan pada tujuan yang hendak dicapai, yaitu menganalisis penerapan higiene sanitasi pada katering di Kota Palangka Raya.

Populasi penelitian ini adalah seluruh katering di Kota Palangka Raya dengan jumlah sampel 10 katering yang terdiri dari 3 katering golongan A2 dan 7 katering golongan A3. Sampel merupakan katering golongan A2 dan golongan A3 yang masih belum terdaftar pada dinas kesehatan, dinas perindustrian dan perdagangan serta dinas pariwisata Kota Palangka Raya. Sampel dipilih berdasarkan teknik purposive dengan pertimbangan waktu, tenaga, dan dana sehingga tidak mengambil sampel besar dan jauh.

Pengambilan data primer dilakukan dengan wawancara pada 10 pemilik katering serta tenaga pengolah makanan dan observasi dari segi bangunan, fasilitas sanitasi, peralatan, ketenagaan, makanan, prinsip higiene sanitasi Jasa boga yang meliputi pemilihan bahan makanan, penyimpanan bahan makanan, pengolahan makanan, pengolahan makanan, penyimpanan makanan jadi/masak, pengangkutan makanan, serta penyajian makanan. Kualitas mikrobiologi (uji E.coli) dilakukan dengan pemeriksaan sampel sayuran masak dari 3 katering golongan A2 serta mendeskripsikan jenis 
makanan dan menilai komposisi gizi makanan yang disajikan. Penelitian ini telah memperoleh persetujuan etik dari komisi etik penelitian kesehatan Fakultas Kesehatan Masyarakat, Universitas Airlangga nomor 189-KEPK.

Hasil yang diperoleh dilihat berdasarkan penilaian dari formulir dengan bobot yang telah ditentukan dalam PERMENKES RI No.1096/ MENKES/PER/VI2011 untuk golongan A2: nilai 70-74, golongan A3: nilai 74-83. Dalam prinsip higiene sanitasi makanan yang dilaksanakan oleh katering, hasil dianalisis secara deskriptif, dan kualitas mikrobiologi pada masakan sayuran dilakukan dengan uji laboratorium pemeriksaan E.coli.

\section{HASIL DAN PEMBAHASAN}

\section{Persyaratan Teknis Bangunan}

Bangunan merupakan bagian utama dari persyaratan fisik penyelenggaraan makanan di mana salah satu bagiannya adalah dapur. Dapur merupakan suatu ruangan atau tempat khusus yang memiliki perlengkapan dan peralatan untuk mengolah makanan sehingga perlu diperhatikan kelaikan fisik dan kebersihannya (Napitupulu, 2010).

Berdasarkan hasil uji kelaikan fisik bangunan, seluruh katering memenuhi persyaratan teknis dalam konstruksi bangunan, pencahayaan, ventilasi, ruang pengolahan makanan (barang tersusun rapi) dan memiliki kamar ganti pakaian. Hasil selengkapnya dapat dilihat dalam Tabel 1.

Konstruksi bangunan untuk kegiatan jasa boga harus kokoh dan aman, selalu dalam keadaan bersih secara fisik dan bebas dari barang-barang sisa atau bekas yang ditempatkan sembarangan. Konstruksi dapur sebaiknya menghindari terbentuknya sudutsudut dan celah mati yang sulit dibersihkan. Bagian ruangan seperti ini kemungkinan besar akan menjadi tempat akumulasi kotoran atau tempat bersarangnya serangga dan hewan pengerat (Purnawijayanti, 2011).

Pencahayaan yang memadai sangat penting untuk menjamin bahwa semua peralatan yang digunakan di dapur dan di ruang penyajian dalam keadaan bersih. Selain itu pencahayaan yang memadai juga sangat penting untuk menjamin
Tabel 1. Hasil Kelaikan Fisik Bangunan Katering Golongan A2 dan A3 di Kota Palangka Raya

\begin{tabular}{lcc}
\hline \multicolumn{1}{c}{ Variabel } & $\begin{array}{c}\text { Memenuhi } \\
\boldsymbol{n}=\mathbf{1 0}\end{array}$ & $\begin{array}{c}\text { Tidak memenuhi } \\
n=10\end{array}$ \\
\hline Halaman & 9 & 1 \\
Konstruksi bangunan & 10 & 0 \\
Lantai & 9 & 1 \\
Dinding dan langit- & & \\
langit & 9 & 1 \\
Pencahayaan & 10 & 0 \\
Ventilasi/penghawaan & 10 & 0 \\
Ruang pengolahan & & \\
makananHHH & & \\
Luas lantai & 9 & 1 \\
Kerapian barang & 10 & 0 \\
Kamar ganti pakaian & 10 & 0 \\
\hline
\end{tabular}

keberhasilan pekerjaan preparasi, pengolahan, penyajian, dan penyimpanan makanan. Sistem ventilasi dapur harus dibuat sedemikian rupa sehingga dapat dihindari terjadinya kondensasi di ruangan dapur yang dapat memacu pertumbuhan jamur dan bakteri. Seluruh katering sudah memiliki ventilasi dan pencahayaan yang cukup dalam dapur. Ventilasi pada katering sudah didesain untuk dapat mengeluarkan uap, kondensasi, kelebihan panas, dan bau dari ruangan. Asap yang dihasilkan dari berbagai proses pemasakan seperti pembakaran, dapat dikeluarkan dari ruangan dapur, sehingga tidak mengganggu pekerja. Namun demikian, dapur khusus katering golongan A3 memerlukan alat penghisap (exhaust fan).

Ruang pengolahan makanan menurut kelaikan fisik higiene sanitasi Jasa boga terbagi atas 2 (dua) bagian penilaian, yaitu: (1) tersedia luas lantai yang cukup untuk pekerja pada bangunan, terpisah dari tempat tidur atau tempat mencuci makanan (dalam luas lantai ada satu katering belum memenuhi persyaratan karena keadaan ruangan dapur yang sempit, dan tidak sesuai dengan jumlah pekerja); (2) ruangan bersih dari barang yang tidak berguna.

Penilaian bangunan untuk kategori halaman, lantai, dinding, langit-langit, serta ruang pengolahan makanan telah dipenuhi persyaratan teknis jasa boga oleh 9 dari 10 katering sesuai dengan PERMENKES RI No.1096/MENKES/ PER/VI2011.

Lokasi pengolahan makanan dalam penelitian sesuai dengan Mawaddah yang dikutip Kusumawati 
(2013) terhadap jasa boga di mana lokasi pengolahan makanan yang berdekatan dengan sumber pencemaran sangat rentan terkontaminasi zat membahayakan yang berasal dari lingkungan sekitar dan memengaruhi kualitas makanan yang dihasilkan. Katering dalam penelitian ini memiliki lokasi yang bersih dan jauh (berjarak 500 meter) dari tempat pembuangan sampah dan halaman terpelihara bersih. Halaman sesuai dengan persyaratan teknis higiene sanitasi jasa boga yaitu bersih, tidak bersemak, tidak banyak lalat dan tersedia tempat sampah yang bersih dan tertutup, tidak terdapat tumpukan barang yang dapat menjadi sarang tikus, dan tidak terdapat genangan air. Salah satu katering dalam penelitian ini belum memenuhi persyaratan halaman, dikarenakan lokasi katering dalam perumahan konstruksi kayu, berdiri di atas sungai, dan masih ada sampah yang mengapung di sekitar lokasi tersebut.

Lantai merupakan bagian bangunan berupa suatu luasan yang dibatasi dinding-dinding sebagai tempat melakukan aktivitas, kedap air, rata, tidak licin, tidak retak, terpelihara dan mudah dibersihkan. Hasil dari penilaian kelaikan fisik lantai, terdapat 1 katering yang belum memenuhi persyaratan. Lantai terbuat dari semen, dan terlihat retakan. retakan pada lantai lapisi dengan karpet yang terbuat dari plastik. Dinding dan langit-langit dapur menurut kelaikan fisik higiene sanitasi jasa boga dibuat dari bahan yang tidak menyerap partikel dan mudah dibersihkan. Apabila digunakan pelapis dinding bahannya harus tidak beracun (nontoxic). Dinding harus rata, tidak lembab, dan berwarna terang, sedangkan untuk langit-langit harus menutup seluruh atap bangunan, dan tinggi minimal 2,4 meter dari lantai. Satu katering belum memenuhi persyaratan teknis dalam dinding dikarenakan dinding masih lembab, terlihat bekas rembesan air hujan dan tidak dilapisi dengan keramik.

Sesuai dengan penelitian yang dilakukan Nugroho (2014), langit-langit tidak boleh bergelombang dan harus memiliki alat pembuangan asap untuk mencegah terjadinya pengumpulan asap sehingga dapat mengontaminasi makanan yang telah diproduksi. Katering dalam penelitian ini sudah memiliki langit-langit yang tidak bergelombang, namun masih belum memiliki alat pembuangan asap. Pembuangan asap hasil pemasakan masih melalui lubang ventilasi maupun jendela dalam bangunan.

Hanya ada 1 dari 10 katering yang memenuhi persyaratan teknis dalam kategori pintu dan jendela. Pintu dan jendela harus memiliki alat penahan bau dan dapat membuka kedua arah. Katering yang tidak memenuhi persyaratan teknis dalam masih menggunakan pintu dan jendela membuka satu arah, dan masih belum memiliki alat penahan bau. Pada pintu dan jendela harus memiliki alat penahan bau. Fungsi memiliki alat penahan serangga dan bau adalah agar higiene makanan tetap terjaga. Serangga seperti lalat merupakan carrier kuman yang dapat mencemari/ mengkontaminasi bahan makanan, makanan maupun minuman yang diproduksi. Penahan bau difungsikan untuk tidak mengontaminasi aroma makanan sehingga aroma makanan tetap terjaga sesuai dengan jenis masakan maupun ciri khas dari masakan tersebut.

Bangunan jasa boga atau katering yang terdiri dari lokasi, halaman, kontruksi bangunan, dinding, lantai, langit-langit, pintu, jendela, pencahayaan, ventilasi hingga ruang pengolahan makanan harus memenuhi kelaikan fisik sesuai dengan ketentuan pemerintah dalam higiene sanitasi Jasa boga. Berdasarkan hasil diketahui katering golongan A2 dan A3 di Kota Palangka Raya masih belum seluruhnya memenuhi kelaikan fisik bangunan. Hal ini sama dengan penelitian yang dilakukan oleh Febriyanti (2011) tentang penerapan higiene sanitasi kelaikan fisik bangunan pada katering PUTA 14 di Surabaya, di mana hasil yang diperoleh masih belum seluruhnya memenuhi persyaratan.

\section{Fasilitas Sanitasi}

Berdasarkan rekap hasil uji kelaikan fisik fasilitas sanitasi diperoleh data seluruh katering telah memenuhi persyaratan teknis dalam pembuangan air kotor (limbah) dan fasilitas pencucian. Terdapat 1 (satu) dari 7 (tujuh) katering khusus golongan A3 memiliki alat penangkap lemak. Alat penangkap lemak berfungsi untuk memisahkan minyak dari air, sehingga minyak atau lemak tidak membeku dan menggumpal di pipa pembuangan. Fasilitas sanitasi air bersih memiliki 
skor rata-rata 4,4. Sumber air katering berasal dari PAM dan sanyo (pompa tangan tertutup); fasilitas sanitasi untuk cuci. Fasilitas cuci tangan sudah memiliki sabun dan bersih; fasilitas sanitasi pembuangan sampah memiliki skor rata-rata 1,4.

Seluruh katering belum memenuhi persyaratan teknis dalam fasilitas sanitasi alat pembuangan sampah. Tempat sampah yang digunakan masih terbuka, sehingga menimbulkan serangga seperti lalat berkeliaran di sekitar tempat sampah. Syarat tempat sampah menurut PERMENKES RI No. 1096/MENKES/PER/VI/2011 antara lain harus terpisah antara sampah basah (organik) dan sampah kering (an organik), tertutup, tersedia dalam jumlah yang cukup dan diletakkan sedekat mungkin dengan sumber produksi sampah, namun dapat menghindari kemungkinan tercemarnya makanan oleh sampah dari hasil limbah produksi maupun sisa produksi.
Pemeliharaan sanitasi merupakan salah satu kunci dalam terpenuhinya higiene sanitasi makanan. Kejadian pencemaran makanan sering disebabkan oleh tidak terpeliharanya higiene sanitasi pekerja yang terlibat dalam proses pengolahan, pemasakan dan penyajian makanan. Menurut penelitian Cahyaningsih (2009), terdapat hubungan yang sangat signifikan antara variabel mencuci tangan sebelum bekerja dan tidak mencuci tangan dengan sabun setelah dari WC dengan jumlah angka kuman. Hal ini sangat berkaitan dengan tersedianya fasilitas mencuci tangan yang dilengkapi dengan sabun serta perilaku higiene penjamah makanan. Fasilitas sanitasi yang baik harus tersedia dalam menunjang kegiatan produksi makanan. Tindakan ini harus dilakukan dalam upaya pemeliharaan higiene sanitasi pekerja. Penyediaan air bersih, pembuangan air limbah/ air kotor, adanya fasilitas cuci tangan dan toilet makanan. Tindakan ini harus dilakukan dalam

Tabel 2. Hasil Kelaikan Fisik Fasilitas Sanitasi, Peralatan, dan Ketenagaan Katering Golongan A2 dan A3 di Kota Palangka Raya

\begin{tabular}{|c|c|c|}
\hline \multirow{2}{*}{ Variabel } & \multicolumn{2}{|c|}{ Hasil } \\
\hline & $m e a n \pm \mathrm{SD}$ & $N$ \\
\hline \multicolumn{3}{|l|}{ Fasilitas Sanitasi } \\
\hline 1. Kelaikan air bersih, skor (mean $\pm \mathrm{SD})$ & $4,4 \pm 0,84$ & 10 \\
\hline 2. Katering yang mempunyai pembuangan air kotor, $n$ & - & 10 \\
\hline 3. Katering yang mempunyai grease trap (khusus golongan A3), $n$ & - & 1 \\
\hline 4. Kelaikan fasilitas cuci tangan, skor (mean $\pm \mathrm{SD})$ & $2 \pm 0$ & 10 \\
\hline 5. Kelaikan tempat pembuangan sampah, skor (mean $\pm \mathrm{SD}$ & $1,4 \pm 0,51$ & 10 \\
\hline 6. Katering yang mempunyai alat pembuang asap, $n$ & - & 0 \\
\hline 7. Kelaikan fasilitas pencucian, skor (mean $\pm \mathrm{SD}$ ) & $2 \pm 0$ & 10 \\
\hline \multicolumn{3}{|l|}{ Peralatan } \\
\hline \multicolumn{3}{|l|}{ 1. Kelaikan peralatan } \\
\hline Perlindungan alat makan dan masak, skor (mean $\pm \mathrm{SD})$ & $1,7 \pm 0,48$ & 10 \\
\hline Perlindungan terhadap bahan racun/pestisida, skor (mean $\pm \mathrm{SD})$ & $3,1 \pm 0,32$ & 10 \\
\hline Perlindungan terhadap binatang pengganggu, skor (mean $\pm \mathrm{SD})$ & $2,5 \pm 0,53$ & 10 \\
\hline \multicolumn{3}{|l|}{ 2. Katering dengan penggunaan alat makan dan masak sekali } \\
\hline pakai yang telah memenuhi syarat, $n$ & - & 10 \\
\hline 3. Katering yang menerapkan proses pencucian alat sesuai ketentuan, $n$ & - & 1 \\
\hline 4. Katering yang memiliki lemari es, $n$ & - & 10 \\
\hline 5. Kelaikan Freezer khusus katering golongan A3, skor (mean \pm SD) & $2,14 \pm 0,38$ & 10 \\
\hline \multicolumn{3}{|l|}{ Ketenagaan } \\
\hline 1. Ketenagaan, skor (mean $\pm \mathrm{SD})$ & $3,8 \pm 0,42$ & 10 \\
\hline 2. Perilaku karyawan, skor (mean $\pm \mathrm{SD})$ & $3,3 \pm 0,48$ & 10 \\
\hline 3. Katering di mana penampilan karyawan telah memenuhi persyaratan, $n$ & - & 10 \\
\hline
\end{tabular}


upaya pemeliharaan higiene sanitasi pekerja. Penyediaan air bersih, pembuangan air limbah/ air kotor, adanya fasilitas cuci tangan dan toilet yang sesuai dengan jumlah pekerja, kelaikan pembuangan sampah, tersedianya alat pembuangan asap hingga kelaikan fasilitas pencucian merupakan variabel dalam penentuan kelaikan fisik fasilitas sanitasi fasilitas sanitasi pada katering.

\section{Peralatan}

Berdasarkan tabel 2 diketahui seluruh katering sudah memenuhi persyaratan fisik peralatan dalam alat makan dan lemari es. Terdapat 7 dari 10 katering sudah memenuhi persyaratan fisik dalam perlindungan terhadap alat makan dan masak. Khusus katering golongan A3 terdapat 5 dari 7 katering sudah memenuhi persyaratan dalam kendaraan pengangkut. Terdapat 1 dari 10 katering sudah memenuhi persyaratan fisik dalam proses pencucian alat. Perlindungan terhadap bahan racun/pestisida diperoleh skor rata-rata (mean) 3,1 ; perlindungan terhadap binatang pengganggu diperoleh skor rata-rata (mean) 2,5; kelaikan freezer khusus katering golongan A3 skor ratarata (mean) 2,14.

Perlindungan terhadap peralatan makan dan masak dilihat dalam cara pembersihan, penyimpanan, penggunaan, dan pemeliharaannya. Menurut Peraturan Menteri Perindustrian, tahapan dalam perlindungan alat meliputi pembersihan kasar, menggunakan detergen alkali, membilas dengan air panas, penyucihamaan (sesudah pembersihan dan pembilasan, digunakan larutan desinfektan), pembilasan, pengeringan, dan penyimpanan.

Perlindungan terhadap binatang pengganggu dilihat dari penanganan maupun pencegahan terjadinya kontaminasi makanan akibat dari adanya binatang pengganggu seperti serangga, tikus, hewan peliharaan dan hewan pengganggu lainnya. Berdasarkan hasil, ada 4 (empat) katering yang masih terlihat memiliki binatang peliharaan di sekitar area bangunan produksi.

Proses pencucian alat sesuai dengan PERMENKES RI No. 1096/MENKES/PER/ VI/2011 yaitu proses pencucian melalui tahapan mulai dari pembersihan sisa makanan, perendaman, pencucian dan pembilasan. Setiap katering harus melaksanakan tahap pencucian tersebut, sehingga sisa-sisa bahan makanan/makanan di peralatan tidak menempel, dan bersih untuk mencegah terjadinya kontaminasi pada penggunaan peralatan selanjutnya.

\section{Ketenagaan}

Menurut Fatmawati (2013), faktor kebersihan penjamah atau pengelola makanan yang disebut higiene personal merupakan prosedur menjaga kebersihan dalam pengelolaan makanan yang aman dan sehat. Prosedur menjaga kebersihan merupakan perilaku bersih untuk mencegah kontaminasi pada makanan yang ditangani.

Berdasarkan hasil uji kelaikan fisik ketenagaan diketahui seluruh katering sudah memenuhi persyaratan teknis dalam penampilan karyawan. Persyaratan teknis dalam ketenagaan dan perilaku karyawan diperoleh skor rata-rata (mean) masing-masing 3,8 dan 3,3. Menurut persyaratan teknis higiene sanitasi makanan jasa boga dalam kelaikan fisik ketenagaan sesuai dengan PERMENKES RI No. 1096/MENKES/ PER/VI/2011 yaitu semua karyawan yang bekerja bebas dari penyakit menular, seperti penyakit kulit, bisul, luka terbuka dan infeksi saluran pernafasan atas (ISPA). Karyawan yang bekerja pada katering masih banyak yang belum diperiksa secara rutin kesehatannya, sehingga belum bisa dikatakan bebas dari penyakit. Menurut Nugroho (2014) dalam penelitiannya tentang penjamah makanan yang memeriksakan kesehatan rutin, nilai $90 \%$ penjamah makanan yang rutin memeriksakan kesehatan termasuk kategori kurang baik, karena kemungkinan besar penyakit sudah menular sebelum dilakukan pemeriksaan sehingga terlambat untuk dilakukan pencegahan. Sesuai dengan persyaratan higiene sanitasi, seharusnya karyawan memiliki surat keterangan berbadan sehat dan rutin memeriksakan diri minimal 6 bulan sekali (Permenkes RI, 2011).

Perilaku karyawan katering yang sesuai higiene sanitasi jasa boga menurut Permenkes RI (2011) pada saat menjamah/produksi makanan adalah tidak merokok, tidak makan atau mengunyah, tidak memakai perhiasan, kecuali cincin kawin yang tidak berhias (polos), tidak menggunakan peralatan dan fasilitas yang bukan 
untuk keperluannya, selalu mencuci tangan sebelum bekerja, setelah bekerja dan setelah keluar dari toilet/jamban, selalu memakai pakaian kerja dan pakaian pelindung dengan benar, selalu memakai pakaian kerja yang bersih yang tidak dipakai di luar tempat jasa boga, tidak banyak berbicara dan selalu menutup mulut pada saat batuk atau bersin dengan menjauhi makanan atau keluar dari ruangan, tidak menyisir rambut di dekat makanan yang akan dan telah diolah. Hasil observasi pada tenaga penjamah makanan katering, masih terdapat karyawan yang mengobrol pada saat kegiatan produksi makanan. Sebagian karyawan sudah menggunakan penutup kepala khusus pada saat memasak, namun ada juga yang masih menggunakan handuk/kain pengikat kepala.

Penampilan karyawan menurut persyaratan teknis higiene sanitasi makanan jasa boga dalam kelaikan fisik penampilan karyawan sesuai dengan PERMENKES RI No. 1096/MENKES/PER/ VI/2011 yaitu pakaian kerja dalam keadaan bersih, rambut pendek dan tubuh bebas perhiasan selama bekerja di produksi makanan.

\section{Makanan}

Berdasarkan rekap hasil uji kelaikan fisik makanan diketahui seluruh katering telah memenuhi persyaratan teknis makanan dalam pemilihan bahan makanan, bahan makanan terolah dan penanganan sebelum penyajian. Terdapat 1 (satu) dari 10 katering sudah memenuhi persyaratan teknis makanan dalam penanganan makanan sebelum penyajian. Namun seluruh katering belum memenuhi persyaratan teknis dalam penanganan pasca penyajian.

Penilaian kelaikan fisik pemilihan bahan makanan dinilai melalui sumber makanan, keutuhan dan makanan tidak dalam keadaan rusak. Bahan makanan terolah dilihat dalam kemasan asli, terdaftar, berlabel dan tidak kadaluarsa. Bagian makanan ini sama dengan prinsip higiene sanitasi makanan sesuai dengan PERMENKES RI No. 1096/MENKES/PER/VI/2011 .
Tabel 3. Hasil Kelaikan Fisik Makanan Katering Golongan A2 dan A3 di Kota Palangka Raya

\begin{tabular}{|c|c|c|}
\hline Variabel & $\begin{array}{c}\text { Memenuhi } \\
\text { kelaikan fisik } \\
\text { makanan }\end{array}$ & $\begin{array}{c}\text { Belum } \\
\text { memenuhi } \\
\text { kelaikan fisik } \\
\text { makanan }\end{array}$ \\
\hline $\begin{array}{l}\text { Pemilihan bahan } \\
\text { makanan }\end{array}$ & 10 & 0 \\
\hline $\begin{array}{l}\text { Bahan makanan } \\
\text { terolah }\end{array}$ & 10 & 0 \\
\hline $\begin{array}{l}\text { Penanganan sebelum } \\
\text { penyajian }\end{array}$ & 10 & 0 \\
\hline $\begin{array}{l}\text { Penanganan pasca } \\
\text { penyajian }\end{array}$ & 1 & 9 \\
\hline
\end{tabular}

\section{Hasil Kelaikan Fisik Higiene Sanitasi Makanan pada Katering}

Berdasarkan persyaratan fisik higiene sanitasi jasa boga pada katering golongan A2 dan golongan A3 di Kota Palangka Raya dengan menggunakan instrumen pemeriksaan kelaikan fisik higiene sanitasi yang dilihat dari bangunan, fasilitas sanitasi, peralatan, ketenagaan dan makanan sesuai PERMENKES RI No. 1096/MENKES/ $\mathrm{PER} / \mathrm{VI} / 2011$ diperoleh hasil katering golongan A2 : katering 1 skor 57 , katering 2 skor 58 , katering 3 skor 53; golongan A3 katering 4 skor 70, katering 5 skor 60 , katering 6 skor 62 , katering 7 skor 65 , katering 7 skor 64 , katering 8 skor 63 , dan katering 9 skor 68 (Tabel 3). Hasil pemeriksaan kelaikan fisik katering seluruhnya tidak laik fisik.

Hasil penelitian menunjukkan seluruh katering masih belum memenuhi kelaikan fisik dalam penerapan higiene sanitasi jasa boga. Kategori diketahui hasil skor laik higiene yaitu katering golongan A2 nilai 70-74; katering golongan A3 nilai 74-83. Hasil penelitian ini sama dengan penelitian yang dilakukan oleh Febriyanti (2011) dalam penerapan higiene sanitasi di katering PUTA 14 Surabaya belum sepenuhnya memenuhi persyaratan.

Berdasarkan hasil penelitian, kelaikan fisik berperan penting dalan higiene sanitasi jasa boga. Perbaikan konstruksi bangunan, peralatan, fasilitas sanitasi, ketenagaan serta makanan yang dihasilkan 
Tabel 4. Nilai Uji Kelaikan Fisik Katering Golongan A2 dan A3 di Kota Palangka Raya

\begin{tabular}{lccl}
\hline & Katering & Skor & Klasifikasi \\
\hline \multirow{3}{*}{ Golongan A2 } & 1 & 57 & Tidak laik higiene \\
& 2 & 58 & Tidak laik higiene \\
& 3 & 53 & Tidak laik higiene \\
\hline & 4 & 70 & Tidak laik higiene \\
Golongan A3 & 5 & 60 & Tidak laik higiene \\
& 6 & 62 & Tidak laik higiene \\
& 7 & 65 & Tidak laik higiene \\
& 8 & 64 & Tidak laik higiene \\
& 9 & 63 & Tidak laik higiene \\
\hline
\end{tabular}

memiliki kontribusi besar meminimalkan kontaminasi makanan yang dapat menimbulkan kasus keracunan akibat makanan yang diproduksi. Pengawasan dan pelindungan rutin terhadap kelaikan fisik higiene sanitasi jasa boga merupakan suatu kewajiban yang dilakukan oleh seluruh usaha yang bergerak di bidang jasa boga.

\section{Prinsip higiene sanitasi}

Penerapan prinsip higiene sanitasi makanan pada katering golongan A2 dan golongan A3 di Kota Palangka Raya dilihat dari segi pemilihan bahan makanan, penyimpanan bahan makanan, pengolahan makanan, penyimpanan makanan jadi/ masak, pengangkutan hingga penyajian makanan. Menurut Riolita (2014), penjamah makanan sebagian besar menerapkan higiene sanitasi dalam penanganan bahan makanan sehingga kadang terpelihara dengan baik dan terkadang tidak terpelihara dengan baik, tergantung dari tingkat pendidikan dan pengetahuan tentang higiene sanitasi makanan. Hal ini sesuai dengan hasil penelitian yang dilakukan, di mana katering tenaga dengan penjamah makanan yang pernah mengikuti kursus/pelatihan higiene sanitasi (katering 4, katering 7, dan katering 10) terlihat pada perbedaan tingkat perolehan skor kelaikan fisik terhadap katering lainnya.

Pemilihan bahan makanan sudah dilakukan sesuai dengan persyaratan higiene sanitasi jasa boga pada seluruh katering. Pada penyimpanan bahan makanan dan makanan jadi/masak, masih ada katering yang tidak sesuai dengan persyaratan higiene sanitasi makanan. Salah satu katering masih menyimpan beras di lantai. Penyimpanan bahan makanan harus sesuai syarat, yaitu tidak menempatkan bahan makanan langsung bersentuhan dengan lantai. Kondisi fisik bangunan dan penataan bahan makanan, serta tempat atau wadah penyimpanan mempengaruhi dalam tempat penyimpanan bahan makanan maupun makanan jadi/terolah.

Pengolahan makanan sudah dilaksanakan sesuai dengan persyaratan. Pada pengangkutan makanan, prinsip telah dilakukan katering sesuai dengan persyaratan, namun masih ada katering yang belum memiliki alat pendingin dalam kendaraan pengangkut makanan untuk mengangkut bahan makanan seperti daging, udang dan sebagainya, makanan seperti susu cair dan es krim.

\section{Kualitas Mikrobiologi Makanan (Uji E.Coli)}

Menurut Anwar yang dikutip oleh Nurlaela (2011), pangan yang tidak aman dapat menyebabkan penyakit yang disebut dengan foodborne diseases yaitu gejala penyakit yang timbul akibat mengonsumsi pangan yang mengandung bahan/senyawa beracun atau organisme patogen.

Escherichia coli merupakan bakteri yang paling banyak digunakan sebagai indikator sanitasi. Radji, dkk. (2010) menyatakan bahwa Escherichia coli merupakan bakteri indikator kualitas air minum karena keberadaannya di dalam air mengindikasikan bahwa air tersebut terkontaminasi oleh feses, yang kemungkinan juga mengandung mikroorganisme enterik patogen lainnya. Beberapa galur Escherichia coli digolongkan sebagai penyebab diare, yaitu Enteropathogenic Escherichia coli (EPEC), Enteroaggegative Escherichia coli (EAEC), 
Enterotoxigenic Escherichia coli (ETEC), Enteroinvasive Escherichia coli (EIEC) dan Escherichia coli yang memproduksi shigatoxin (STEC). Bakteri Escherichia coli yang ada di dalam air atau makanan biasanya galur Escherichia coli non-patogen walaupun pada beberapa kasus terdapat galur yang patogen seperti enterotoksigenik dan galur Escherichia coli yang memproduksi shiga-toxin. Beberapa penyakit yang disebabkan dari mengonsumsi makanan atau minuman yang terkontaminasi oleh bakteri Escherichia coli dan kondisi sanitasi yang buruk adalah kejang perut, diare berdarah, gangguan ginjal pada anak-anak (fatal), gangguan saraf pada lansia, kegagalan ginjal, gastroentritis, keracunan makanan (Chukwuemeka, 2012).

Penilaian kualitas mikrobiologi makanan dilakukan pada 3 (tiga) katering khusus golongan A2, yaitu katering 1, 2, dan 3, di mana hasil yang diperoleh angka kuman masing-masing katering tersebut $0 / g$ dari sampel sayuran masak. Sampel yang diambil untuk pengujian ini adalah satu porsi sayuran masak. Penempatan sampel makanan dengan menggunakan kantong plastik steril dan sampel diambil menggunakan sendok makan yang sudah disterilkan dengan alkohol $70 \%$. Jumlah sampel yang diambil masing-masing sebanyak $50 \mathrm{ml}$. Menurut penelitian Yunus (2015) ada hubungan yang signifikan antara sanitasi tempat pengolahan makanan dan pengelolaan sampah dengan kontaminasi Escherichia coli pada makanan. Berdasarkan hasil penelitian, angka kuman diperoleh $0 / \mathrm{g}$, sehingga diketahui sanitasi tempat pengolahan makanan tergolong baik. Masih dalam penelitian Yunus (2015) variabel yang memiliki pengaruh paling dominan terhadap kejadian kontaminasi Escherichia coli adalah personal higiene penjamah makanan. Berdasarkan hasil penelitiannya, penjamah makanan memiliki peluang sebesar 27,883 kali terhadap terjadinya kontaminasi Escherichia coli pada makanan dibandingkan dengan variabel lainnya.

\section{KESIMPULAN DAN SARAN}

Kesimpulan dari penelitian ini diketahui seluruh sampel katering masih belum memenuhi kelaikan fisik dalam penerapan higiene sanitasi jasa boga, namun dalam prinsip higiene sanitasi dari masing-masing variabel pada katering sudah ada yang memenuhi persyaratan. Penilaian kualitas mikrobiologi terhadap makanan pada 3 katering menunjukkan angka kuman E.coli 0/g untuk sampel sayuran masak.

Penerapan higiene sanitasi jasa boga pada katering ini diharapkan menjadi acuan memperoleh sertifikat laik higiene serta informasi bagi Dinas Kesehatan untuk verifikasi penerapan higiene sanitasi Jasa boga di Palangka Raya.

\section{DAFTAR PUSTAKA}

Badan POM RI. (2013). Penelusuran Kasus KLB Keracunan di Kabupaten Kapuas Kalimantan Tengah. Diakses dari http://www.pom.go.id//

Cahyaningsih, C., Kushadiwijaya, H.,\& Tholib, A. (2009). Hubungan Higiene Sanitasi dan Perilaku Penjamah Makanan dengan Kualitas Bakteriologis Peralatan Makan di Warung Makan. Berita Kedokteran Masyarakat 25(4), 180-188. Diakses dari http:// http://journal. ugm.ac.id/

Chukwuemeka. (2010). Bacteriological Quality of Food and Water Sold by Vendours and Restaurant in Nsukka Nigeria: Assesment of Coliform Contamination. Journal of Food Technology, 8(4), 175-179.

Fatmawati, S., Rosidi, A., \& Handarsari, E. (2013). Perilaku Higiene Pengolah Makanan Berdasarkan Pengetahuan Tentang Higiene Mengolah Makanan dalam Penyelenggaraan Makanan di Pusat Pendidikan dan Latihan Olahraga Pelajar Jawa Tengah. Jurnal Pangan dan Gizi, 4(8), 45-52. Diakses dari http: // jurnal.unimus.ac.id/index.php/JPDG/article/ download/1167/1221

Febriyanti, P. (2011). Penerapan Higiene Sanitasi Penyelenggaraan Makanan di Catering PUTA 14 Surabaya. Tugas Akhir. Diakses dari http:// adln.lib.unair.ac.id/files/disk1/421/gdlhub-gdls1-2011-febriyanti-21037-fkmhkk-k.pdf

Kementrian Kesehatan RI. (2011). Peraturan Menteri Kesehatan tentang Pedoman Higiene Sanitasi Jasa boga (Permenkes 1096/Menkes/ PER/VI/2011. Diakses dari http://www. s3.amazonaws.com

Kementrian Perindustrian RI. (2010). Peraturan Menteri Perindustrian tentang Pedoman Cara Produksi Pangan Olahan yang Baik (Good 
Manufacturing Practuring Practices). Diakses dari http://www.bpkm.go.id

Kusumawati, T., \& Yudhastuti, R (2013). Higiene dan Sanitasi Makanan Nasi Krawu di Kecamatan Gresik Kabupaten Gresik. Jurnal Kesehatan Lingkungan, 7(1), 38-44.

Napitupulu. (2010). Kebersihan (Hygiene) dan Sanitasi Makanan di Dapur Hotel. Diakses dari http://uda.ac.id/jurnal/files/JUrnal\%205_\%20 Binur.pdf

Nugroho, M., Yudhastuti, R. (2014). Kondisi Higiene Penjamah Makanan dan Sanitasi Kantin di SMAN 15 Surabaya. Diakses dari http://journal.unair.ac.id/download-fullpaperskesling7e98d56024full.pdf.

Nurlaela, E. (2011). Keamanan Pangan dan Perilaku Penjamah Makanan di Instalasi Gizi Rumah Sakit. Media Gizi Masyarakat Indonesia 1(1), 1-7. Diakses dari http: //download.portalgaruda. org/article.php?article $=29772 \&$ val $=2168$

Public Health. (2016). Syarat Higiene Penjamah Makanan. Diakses dari http://publichealthjournal.helpingpeopleideas.com/syarat-higienepenjamah-makanan.

Purnawijayanti. (2011). Sanitasi, Hygiene, dan Keselamatan Kerja dalam Pengolahan Makanan. Yogyakarta: Kanisius.
Radji, M., Puspaningrum, A., \& Sumiati, A. (2010). Deteksi Cepat Bakteri E.coli dalam Sampel Air dengan Metode Polymerase Chain Reaction Menggunakan Primer 16E1 dan 16E2. Makara Sains, 14(1), 39.

Riolita, R.,\& Ismawati, R. (2014). Studi Perilaku Hygiene Penajamah Makanan Jananan Sekolah Dasar (SD) Kompleks di Sidoarjo. E-journal boga, 4(1), 76-79. Diakses dari http: //ejournal. unesa.ac.id/index.php/jurnal-tata-boga/article/ view/10265/13389

Sari, N., Marsaulina, I., \& Chahaya, I. (2012). Higiene Sanitasi Pengelolaan Makanan dan Perilaku Penjamah Makanan di Kantin Sekolah Menengah Atas (SMA) Negeri dan Swasta di Kecamatan Rantau Utara Kabupaten Labuhan Batu tahun 2012. Diakses dari http://download.portalgaruda.org/article. php?article $=51440 \& v a l=4110$

Yunus, S., Umboh, J., \& Pinontoan, O. (2015). Hubungan Personal Higiene dengan Kontaminasi Escherichia coli pada Makanan di Rumah Makan Padang Kota Manado dan Kota Bitung. Diakses dari http: //ejournal.unsrat.ac.id/ index.php/jikmu/article/download/7438/6980 